\title{
Compatibility of entomopathogenic fungi and Azadirachta indica extract against the cotton pink bollworm, Pectinophora gossypiella (Saunders) (Lepidoptera: Gelechiidae) under controlled conditions
}

\author{
Muhammad Asif Farooq ${ }^{1 *}$, Bilal Atta ${ }^{2}$, Muhammad Dildar Gogi ${ }^{3}$, Muhammad Jalal Arif ${ }^{3}$ and Qurban Ali Arain ${ }^{1}$
}

\begin{abstract}
Compatibility of entomopathogenic fungi (EPFs) viz. Verticillium lecanii, Metarhizium anisopliae and Beauveria bassiana with Azadirachta indica extract (alone and in combinations) was evaluated against $2^{\text {nd }}$ instar larvae of the cotton pink bollworm, Pectinophora gossypiella (Saunders) (Lepidoptera: Gelechiidae) under controlled conditions. Results indicated that maximum mortality rate of $P$. gossypiella larvae was recorded at combination of the highest conidial concentrations of $V$. lecanii $+M$. anisopliae $+B$. bassiana along with $A$. indica extract, while minimum mortality rate was recorded at $A$. indica extract alone, 12 days post exposure interval. Maximum mycosis and sporulation from dead cadavers of $P$. gossypiella larvae were recorded at the highest concentration of B. bassiana, while the lowest mycosis and sporulation were recorded at the highest conidial concentrations of $V$. lecanii $+M$. anisopliae $+B$. bassiana along with $A$. indica extract. Maximum percent of pupation and adult emergence in $P$. gossypiella larvae was observed in the treatment, where $A$. indica extract was applied alone, while the minimum percent of pupation and adult emergence was observed at the treatment combination of the highest concentration of $B$. bassiana $+V$. lecanii $+M$. anisopliae along with $A$. indica extract was applied. EPFs proved their enhanced long-term protection potential for cotton crop against $P$. gossypiella. A. indica extract integrated with the EPFs can be a potential alternative to the chemicals and as an effective component of IPM program against $P$. gossypiella.
\end{abstract}

Keywords: Cotton pink bollworm, Pectinophora gossypiella, Entomopathogenic fungi, Azadirachta indica, Virulence, Biological control

\section{Background}

The cotton pink bollworm, Pectinophora gossypiella (Saunders) (Lepidoptera: Gelechiidae), is one of the major economic cotton pests that causes considerable damages

\footnotetext{
* Correspondence: asiff06@hotmail.com

'Department of Entomology, University of Agriculture Faisalabad,

(Sub-Campus Burewala, Vehari), Vehari, Punjab, Pakistan

Full list of author information is available at the end of the article
}

to cotton in Pakistan (Jaleel et al. 2014) and many other countries (Parmar and Patel 2016). Different approaches such as chemical insecticides and growing resistant cultivar (transgenic Bt cotton containing CrylAc toxin) have been used to manage the pest control (Heuberger et al. 2014), but they have not given optimal control levels of the pest (Mohamed et al. 2016). Plant extracts such as Nicotiana tabacium and Azadirachta indica have widely

\section{Springer Open}

(0) The Author(s). 2020 Open Access This article is licensed under a Creative Commons Attribution 4.0 International License, which permits use, sharing, adaptation, distribution and reproduction in any medium or format, as long as you give appropriate credit to the original author(s) and the source, provide a link to the Creative Commons licence, and indicate if changes were made. The images or other third party material in this article are included in the article's Creative Commons licence, unless indicated otherwise in a credit line to the material. If material is not included in the article's Creative Commons licence and your intended use is not permitted by statutory regulation or exceeds the permitted use, you will need to obtain permission directly from the copyright holder. To view a copy of this licence, visit http://creativecommons.org/licenses/by/4.0/. 
been used to control insect pests. A. indica (Neem) has been used for years in Indo-Pak against several insect pests and is still used for stored grain pest (Rajendran and Sriranjini 2008). Due to its broad host range, inexpensive production and no harmful impact on environment (Mathew 2016) makes it a safer alternative method to control some insect pests.

The entomopathogenic fungi (EPFs) are among the most effective and environmental friendly biological control agents that invade their host insect through the cuticle and play a key role in the regulation of insect pest population in natural ecosystem (Niu et al. 2019). EPFs can be used against a wide range of insect pests and their nonspecific actions and antagonistic natures give them broad host range ability (Ong and Vandermeer 2014). More than 700 species of fungi belonging to 90 genera among Beauveria bassiana, Metarhizium anisopliae, Verticillium lecanii, Purpureocillium lilacinum, and Isaria fumosorosea are the widely used ones as biological control agent against many agricultural pests (Khan et al. 2012; Rizwan et al. 2019). The addition of plant extracts which act as both adjuvant (Nursal and Ilyas 2019) and bio-pesticide (Dougoud et al. 2019) can heighten the coverage of leaf and persistence of EPFs (Świergiel et al. 2016) resulting in enhanced performance of EPFs and plant extracts in combination for the suppression of some insect pests such as $P$. gossypiella (Vashisth et al. 2019).

This study aimed to check the effect of EPFs; $B$. bassiana, M. anisopliae and $V$. lecanii and the plant extract (Azadirachta indica) on some biological aspects of $P$. gossypiella under laboratory conditions.

\section{Materials and methods}

\section{P. gossypiella culture}

Different growth stages of $P$. gossypiella larvae were collected from cotton fields where their population did not expose to any insecticidal applications. All the stages of $P$. gossypiella were placed separately in labeled plastic vials and transferred to the laboratory. Larvae were maintained by feeding them on green bolls at $27 \pm 0.5{ }^{\circ} \mathrm{C}$ until pupation. Larval discrepancy on the basis of their sex was performed, following the method of Dharajothi et al. (2010) for moth copulation (Jothi et al. 2016). Moths were released in insect rearing cages measuring $28 \mathrm{~cm}$ height and $24 \mathrm{~cm}$ diameter for egg laying, at the rate of 20 pairs per cage, and were fed upon $1 \mathrm{ml}$ multivitamin and protein mixed with $100 \mathrm{ml}$ honey solution (20\%) along with fresh terminal buds and leaves of cotton brought from unsprayed cotton plot, inserted in a small conical flask contains water to keep them fresh egg lying space for adults (Muralimohan et al. 2009). Water-soaked cotton twigs were placed at the bottom of the flask to maintain the moisture level of the tissues and were replaced every $2^{\text {nd }}$ day. These twigs were transferred into translucent plastic containers $(5 \mathrm{~cm}$ height and $4 \mathrm{~cm}$ diameter) sealed with muslin cloth and rubber band for egg hatching (Parker 2005).

The larvae were maintained in plastic trays on green bolls at $26 \pm 2{ }^{\circ} \mathrm{C}, 65 \pm 5 \%$ R.H. and $11 \mathrm{~h}$ light-13 h dark photoperiod until pupation. The pupae were placed in plastic vials $(4 \times 5 \mathrm{~cm}$ diameter $\times$ height $)$ with a meshwindowed lid and a disk of filter paper at the bottom, retained until adult emergence (Muralimohan et al. 2009). Glass wares were rinsed with distilled water followed by sterilization and were used for the preparation and storing of diet.

\section{Entomopathogenic fungi}

Two commercial formulations of 3 EPFs viz. V. lecanii, $M$. anisopliae and B. bassiana were procured from AgriLife SOM Phytopharma (India) Limited $^{\circ}$ (www.agrilife.in) in the form of talc powder. Formulations, at 2 different concentrations $\left(1 \times 10^{6}\right.$ and $\left.1 \times 10^{8} \mathrm{CFU} / \mathrm{ml}\right)$, were tested against $P$. gossypiella. Hemocytometer and potato dextrose agar (PDA) were used to determine the conidial concentrations and germination in conidial suspension, respectively. Measurement of conidial germination was computed by randomly counting 200 conidia in each plate at $25 \pm 2{ }^{\circ} \mathrm{C}, 18 \mathrm{~h}$ after incubation (Atta et al. 2020).

\section{Preparation of conidial suspensions}

EPF's conidial suspensions concentrations, $1 \times 10^{6} \mathrm{co}-$ nidia $\mathrm{ml}^{-1}$ and $1 \times 10^{8}$ conidia $\mathrm{ml}^{-1}$ alone and in combination with $A$. indica extract were prepared by dissolving in distilled water and in 5\% extract as basic solution while using hemocytometer.

\section{Preparation of Azadirachta indica plant extract}

Plant extract of $A$. indica was prepared by adopting the methodology of Ali et al. (2017). Fresh collected leaves of $A$. indica were sufficiently washed by distilled water and dried in shadow, followed by electric grinding to get fine powder. Fine $A$. indica powder $(50 \mathrm{~g}$ ) was dissolved in distilled water $(500 \mathrm{ml})$ in a 2.5 liter sized conical flask by heating the solution at $60^{\circ} \mathrm{C}$ and shaking the flask continuously with a magnetic stirrer for $6 \mathrm{~h}$. Solution was filtered, using Whatman no. 1 after sieving with muslin cloth to remove any solid particles. Rotary evaporator was used to evaporate the solution in vacuumed conditions in hot air oven at to bring the dry plant extract to a constant volume $50 \mathrm{ml}$. The solution thus obtained was considered as $100 \%$ A. indica extract, stored at $4{ }^{\circ} \mathrm{C}$ for further investigations.

\section{Bioassay}

Thirty fresh molted $2^{\text {nd }}$ instar $P$. gossypiella larvae of uniform brood were treated by immersing them in to the conidial suspension $\left(1 \times 10^{6}\right.$ and $\left.1 \times 10^{8} \mathrm{ml}^{-1}\right)$ 
concentrations, i.e., B. bassiana, $V$. lecanii, $M$. anisopliae and $A$. indica extract (5\%) alone and in combination for $10 \mathrm{~s}$ (Derbalah et al. 2014). After the treatment, larvae were placed into sterile Petri dishes (9-cm diameter) for air drying for $10 \mathrm{~min}$. The treated larvae were maintained in labeled plastic trays with artificial diet for further investigations, i.e., mortality, sporulation, mycosis, pupation and adult emergence under laboratory conditions. Mortality rate was calculated at 4, 8 and 12 days of time intervals after which sporulation and mycosis were computed. Mortality data was calculated by Abbott's formula (Abbott 1925).

$$
\text { Corrected mortality } \%=\left(1-\frac{n \text { in } T \text { after treatment }}{n \text { in } \mathrm{C}_{\mathrm{o}} \text { after treatment }}\right) \times 100
$$

where $n=$ insect population, $T=$ treated, $\mathrm{Co}=$ control

\section{Sporulation and mycosis}

Dead cadavers of P. gossypiella stiffs were collected from treatments where EPFs were applied (alone and in combination), for sporulation and mycosis and were transferred to plastic vials from sterile Petri dishes for refrigeration at $4{ }^{\circ} \mathrm{C}$. Solution of sodium hypochlorite $(0.05 \%)$ was used for surface sterilization of the collected cadavers for 2-3 min, followed by 2-3 washings, using distilled water (Leland and Gore 2016). The cadavers were then placed in the Petri dishes for a week with PDA for incubation at $75 \pm 5 \%$ R.H. and $25 \pm 1{ }^{\circ} \mathrm{C}$. Microscope was used for the observation and identification of external growth of the fungi on the treated cadavers. A drop of Tween-80 was added and stirred for 10 min with distilled water $(20 \mathrm{ml})$ to mix with the cadavers, selected from each replication, which were already mycosed for the determination of sporulation. Hemocytometer coupled with microscope was used to determine the total number of conidia $\mathrm{ml}^{-1}$ (Rizwan et al. 2019).

\section{Assessment of pupation and adult emergence of $P$. gossypiella}

All the remained larvae after treatments were evaluated further reared in plastic trays $(5.5 \mathrm{~cm} \times 6 \mathrm{~cm}$, depth and diameter) with artificial untreated diet (Muralimohan et al. 2009) to allow them to continue their development until pupal stage to calculate percent pupation. Pupae were placed individually in a Petri dish (8-cm diameter) until adults emerged to calculate percent adult emergence.

\section{Statistical analysis}

The data was analyzed with the Statistix (Version 8.1) statistical package, using analysis of variance (ANOVA) in CRD to determine the effects of individual and interacted application of variables. Tukey's HSD test for mean separation was used to compare mean values at $P$ $<0.05$ (Sokal and Rohlf 1995).

\section{Results and discussion}

\section{Mortality rates of $P$. gossypiella}

Thirty $2^{\text {nd }}$ instar larvae of $P$. gossypiella, treated with different EPFs concentrations and A. indica (AI) (alone and/or in combination) showed significant effects at different exposure intervals. At 4 and 8 day intervals, all 3 EPFs combined with $A I$ extract $(B a 2+V l 2+M a 2+A I)$ showed the highest mortality of 48.67 and $57.33 \%$, while lowest the mortality rate, recorded in $B b 1$ (22.27 and 28.93\%), respectively. Similarly at 8 day interval, all the 3 EPFs combined with $A I$ extract $(B a 2+V l 2+M a 2+A I)$ showed the highest mortality rate $(74.67 \%)$, whereas the lowest one (37.33\%) was recorded in $V l 1$. Mortality rates of all treatments was compared to the control, where $0.00,1.33$ and $2.67 \%$ rates were recorded at 4,8 and 12 day intervals, respectively (Table 1 ).

\section{Mycosis and sporulation from dead cadavers of $P$. gossypiella}

Effects of the lowest and the highest concentrations of EPFs, alone and in combination, on percent mycosis and sporulation (conidia $\mathrm{ml}^{-1}$ ) from dead cadavers of treated $2^{\text {nd }}$ instar $P$. gossypiella larvae were recorded highly significant $(P<0.01)$ (percent mycosis: $F_{6,34}=46.7$; sporulation: $\left.F_{6,34}=48.7\right)$. Maximum percent mycosis and sporulation $(94.20 \pm 1.10 \%$ and $157.20 \pm 1.67$ conidia $\mathrm{ml}^{-1}$, respectively) was recorded at the dead cadavers of $B$. bassiana ( $B b 2)$-treated $P$. gossypiella at the highest concentration $\left(1 \times 10^{8}\right.$ conidia $\left.\mathrm{ml}^{-1}\right)$, while the minimum percent mycosis and sporulation $(37.20 \pm 1.31 \%$ and $103.40 \pm 1.05$ conidia $\mathrm{ml}^{-1}$, respectively) was recorded at the dead cadavers of $P$. gossypiella treated with combination of $A$. indica + the highest concentration (1 $\times 10^{8}$ conidia $\mathrm{ml}^{-1}$ ) of $B$. bassiana, $V$. lecanii and $M$. anisopliae $(B b 2+V l 2+M a 2+A I)$ (Table 2). These results indicated that $A I$ demonstrated inhibitory effects on the mycosis and sporulation.

\section{Pupation and adult emergence from treated second larval instar of $P$. gossypiella}

Effects of both lowest and the highest concentrations of EPFs, alone and in combination with $A$. indica extract, while that of the highest concentration of EPF $\left(1 \times 10^{8}\right.$ conidia $\mathrm{ml}^{-1}$ ) on percent pupation and progeny of the $2^{\text {nd }}$ instar $P$. gossypiella larvae, were highly significant $(P<0.01)$ (percent pupation: $F_{11,59}=37.0$; percent adult emergence: $\left.F_{11,59}=22.8\right)$. Maximum percent pupation and adult emergence $(90.67 \pm 1.28 \%$ and $84.00 \pm 2.47 \%$, respectively) from $P$. gossypiella were recorded in control, while minimum percent pupation 
Table 1 Percent mortality (mean $\pm \mathrm{SE}, n=5$ ) of $2^{\text {nd }}$ instar Pectinophora gossypiella larvae due to Beauveria bassiana, Verticillium lecanii, Metarhizium anisopliae concentrations and Azadirachta indica extract (alone and in combination) at different exposure intervals. Means sharing with same lower case letters are not significantly different from each other at 0.05 level of significance, i.e., $P<0.05$

\begin{tabular}{|c|c|c|c|}
\hline Treatments & 4 days & 8 days & 12 days \\
\hline$\overline{B b 1}$ & $22.27 \pm 1.75 p$ & $28.93 \pm 1.23$ nop & $44.80 \pm 2.04 \mathrm{hi}$ \\
\hline$B b 2$ & $26.27 \pm 2.24 \mathrm{op}$ & $34.13 \pm 2.141$ & $53.60 \pm 1.95 \mathrm{de}$ \\
\hline$V / 1$ & $24.67 \pm 2.03 p$ & $31.33 \pm 1.61 \mathrm{mn}$ & $37.33 \pm 2.08 \mathrm{jk}$ \\
\hline$V / 2$ & $24.67 \pm 1.98 p$ & $34.67 \pm 2.43 \mid$ & $44.67 \pm 2.24 \mathrm{hi}$ \\
\hline Ma1 & $27.33 \pm 1.730 p$ & $37.33 \pm 1.91 \mathrm{jk}$ & $46.67 \pm 2.11 \mathrm{fgh}$ \\
\hline Ma2 & $31.33 \pm 2.03 \mathrm{mn}$ & $39.33 \pm 2.13 j \mathrm{k}$ & $50.67 \pm 2.76$ def \\
\hline Al & $23.33 \pm 1.05 p$ & $30.67 \pm 1.59$ nop & $40.67 \pm 2.23 i j$ \\
\hline$B b 2+A l$ & $34.67 \pm 1.211$ & $44.67 \pm 1.92 \mathrm{hi}$ & $60.67 \pm 2.64 c$ \\
\hline$V / 2+A l$ & $37.33 \pm 1.91 \mathrm{jk}$ & $48.67 \pm 1.86 f g$ & $64.67 \pm 1.80 b c$ \\
\hline $\mathrm{Ma} 2+\mathrm{Al}$ & $40.67 \pm 3.38 \mathrm{ij}$ & $54.67 \pm 2.03 \mathrm{de}$ & $66.67 \pm 2.11 b$ \\
\hline$B b 2+V / 2+M a 2+A l$ & $48.67 \pm 2.29 f g$ & $57.33 \pm 2.80 \mathrm{~cd}$ & $74.67 \pm 2.43 a$ \\
\hline Control & $0.00 \pm 0.00 q$ & $1.33 \pm 0.37 q$ & $2.67 \pm 0.56 q$ \\
\hline
\end{tabular}

Bb1 Beauveria bassiana $\left(1 \times 10^{6}\right.$ conidia $\left.\mathrm{ml}^{-1}\right)$, Bb2 Beauveria bassiana $\left(1 \times 10^{8}\right.$ conidia $\left.\mathrm{ml}^{-1}\right)$, Vl1 Verticillium lecanii $\left(1 \times 10^{6}\right.$ conidia $\left.\mathrm{ml}^{-1}\right)$, V/2 Verticillium lecanii $(1$

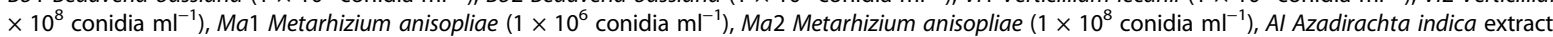

and adult emergence were zero recorded in $P$. gossypiella treated with a combination of the highest concentration of B. bassiana + V. lecanii + M. anisopliae $\left(1 \times 10^{8}\right.$ conidia $\left.\mathrm{ml}^{-1}\right)$ and $A$. indica $(B b 2+V l 2+M a 2+A I)$. Alone $A$. indica extract-treated $P$. gossypiella demonstrated $87.33 \pm 1.73 \%$ pupation and $64.67 \pm 3.08 \%$ adult emergence (Table 3).

Table 2 Percent mycosis and sporulation (conidia $\mathrm{ml}^{-1}$ ) (mean $\pm \mathrm{SE}, n=5$ ) from dead cadavers of $2^{\text {nd }}$ instar Pectinophora gossypiella larvae due to the highest concentrations of Beauveria bassiana, Verticillium lecanii, Metarhizium anisopliae $\left(1 \times 10^{8}\right.$ conidia $\mathrm{ml}^{-1}$ ) (alone and in combination). Means sharing with same lower case letters are not significantly different from each other at 0.05 level of significance, i.e., $P<0.05$

\begin{tabular}{|c|c|c|}
\hline Treatments & Percent mycosis & Sporulation (conidia $\mathrm{ml}^{-1}$ ) \\
\hline$B b 1$ & $87.40 \pm 1.06 a$ & $147.40 \pm 1.04 a b$ \\
\hline$B b 2$ & $94.20 \pm 1.67 a$ & $157.20 \pm 1.10 a$ \\
\hline$B b 2+A l$ & $51.20 \pm 1.45 \mathrm{~cd}$ & $126.40 \pm 1.17$ def \\
\hline$V / 1$ & $82.20 \pm 1.55 a$ & $142.20 \pm 1.24 b c$ \\
\hline$V / 2$ & $87.20 \pm 1.30 \mathrm{a}$ & $146.40 \pm 1.05 a b c$ \\
\hline$V / 2+A l$ & $43.20 \pm 0.86 \mathrm{de}$ & $117.20 \pm 1.05 f$ \\
\hline Ma1 & $61.40 \pm 1.20 \mathrm{bc}$ & $129.20 \pm 0.88$ de \\
\hline Ma2 & $65.20 \pm 1.24 b$ & $135.20 \pm 1.15 \mathrm{~cd}$ \\
\hline $\mathrm{Ma} 2+\mathrm{Al}$ & $48.40 \pm 1.06 \mathrm{de}$ & $123.20 \pm 1.24 \mathrm{ef}$ \\
\hline$B b 2+V / 2+M a 2+A l$ & $37.20 \pm 1.05 e$ & $103.40 \pm 1.31 \mathrm{~g}$ \\
\hline Control & $0.00 \pm 0.00 f$ & $0.00 \pm 0.00 \mathrm{~h}$ \\
\hline
\end{tabular}

Bb1 Beauveria bassiana $\left(1 \times 10^{6}\right.$ conidia $\left.\mathrm{ml}^{-1}\right)$, Bb2 Beauveria bassiana $\left(1 \times 10^{8}\right.$ conidia $\left.\mathrm{ml}^{-1}\right)$, V/1 Verticillium lecanii $\left(1 \times 10^{6}\right.$ conidia $\left.\mathrm{ml}^{-1}\right), \mathrm{V} / 2$ Verticillium lecanii $\left(1 \times 10^{8}\right.$ conidia $\left.\mathrm{ml}^{-1}\right)$, Ma1 Metarhizium anisopliae $\left(1 \times 10^{6}\right.$ conidia $\left.\mathrm{ml}^{-1}\right)$, Ma2 Metarhizium anisopliae $\left(1 \times 10^{8}\right.$ conidia $\left.\mathrm{ml}^{-1}\right)$, Al Azadirachta indica extract
The EPFs conidial suspension concentrations alone, or combined with, $A$. indica extract showed promising potentials against $P$. gossypiella larvae by causing significantly high mortality rates after treatment within 4,8 and 12 day intervals. B. bassiana, V. lecanii and $M$. anisopliae concentrations and $A$. indica extract (alone and in combination) at different exposure intervals showed

Table 3 Percent pupation and percent adult emergence (mean $\pm \mathrm{SE}, n=5$ ) of $2^{\text {nd }}$ instar Pectinophora gossypiella larvae due to Beauveria bassiana, Verticillium lecanii, Metarhizium anisopliae concentrations and Azadirachta indica extract (alone and in combination). Means sharing with same lower case letters are not significantly different from each other at 0.05 level of significance, i.e., $P<0.05$

\begin{tabular}{|c|c|c|}
\hline Treatments & Percent pupation & Percent adult emergence \\
\hline$B b 1$ & $80.67 \pm 2.08 \mathrm{ab}$ & $57.33 \pm 2.80 \mathrm{bc}$ \\
\hline$B b 2$ & $77.33 \pm 2.18 a b c$ & $54.67 \pm 2.24 \mathrm{bcd}$ \\
\hline$V / 1$ & $64.67 \pm 2.61 \mathrm{~cd}$ & $41.33 \pm 2.24 \mathrm{de}$ \\
\hline$V / 2$ & $74.00 \pm 3.11 b c$ & $47.33 \pm 2.88 \mathrm{cde}$ \\
\hline Ma1 & $54.00 \pm 3.03 d$ & $32.67 \pm 2.34 \mathrm{ef}$ \\
\hline Ma2 & $57.33 \pm 3.87 d$ & $34.00 \pm 3.25 \mathrm{e}$ \\
\hline Al & $87.33 \pm 1.73 a b$ & $64.67 \pm 3.08 b$ \\
\hline$B b 2+A l$ & $27.33 \pm 1.73 e$ & $18.00 \pm 2.34 \mathrm{fg}$ \\
\hline$V / 2+A l$ & $14.00 \pm 1.28 \mathrm{ef}$ & $7.33 \pm 0.87 g h$ \\
\hline $\mathrm{Ma} 2+\mathrm{Al}$ & $24.67 \pm 1.38 \mathrm{e}$ & $14.67 \pm 1.38 \mathrm{gh}$ \\
\hline$B b 2+V / 2+M a 2+A l$ & $0.00 \pm 0.00 f$ & $0.00 \pm 0.00 \mathrm{~h}$ \\
\hline Control & $90.67 \pm 1.28 a$ & $84.00 \pm 2.47 a$ \\
\hline
\end{tabular}

Bb1 Beauveria bassiana $\left(1 \times 10^{6}\right.$ conidia $\left.\mathrm{ml}^{-1}\right)$, Bb2 Beauveria bassiana $\left(1 \times 10^{8}\right.$ conidia $\left.\mathrm{ml}^{-1}\right)$, VI1 Verticillium lecanii $\left(1 \times 10^{6}\right.$ conidia $\left.\mathrm{ml}^{-1}\right), \mathrm{V} / 2$ Verticillium lecanii $\left(1 \times 10^{8}\right.$ conidia $\left.\mathrm{ml}^{-1}\right)$, Ma1 Metarhizium anisopliae $\left(1 \times 10^{6}\right.$ conidia $\left.\mathrm{ml}^{-1}\right)$, Ma2 Metarhizium anisopliae $\left(1 \times 10^{8}\right.$ conidia $\left.\mathrm{ml}^{-1}\right)$, Al Azadirachta indica extract 
the highest mortality rates. Similarly, at 8 day intervals, all the 3 EPFs combined with $A I$ extract $(M a 2+V l 2+$ $M a 2+A I)$ showed the highest mortality rate (74.67\%). In the present investigations, $P$. gossypiella pupation as well as adult emergence were also significantly affected. $B$. bassiana, $V$. lecanii and $M$. anisopliae concentrations and $A$. indica extract (alone and in combination) at different exposure intervals caused high mortality rates among the treated $2^{\text {nd }}$ instar $P$. gossypiella larvae due to their effects on specific hydrolytic enzyme such as proteinase, chitinase and lipase that affect cuticle (Kurtti and Keyhani 2008).

Introduction of an exogenous biological agent into an environment, with the aim towards its permanent establishment to control the pests present therein has been an effective technique over the long term (Kenis et al. 2017). Maximum percent mycosis and sporulation was recoded from the dead cadavers of $B$. bassiana-treated $P$. gossypiella at $1 \times 10^{8}$ conidia $\mathrm{ml}^{-1}$ concentration, while minimum percent mycosis and sporulation was recoded from the dead cadavers of combination of the highest concentrations of $B$. bassiana $+V$. lecanii $+M$. anisopliae. The results are in line with the findings of Riasat et al. (2011) who reported that the maximum mycosis $(86.47 \%)$ and sporulation (153.22 conidia $\mathrm{ml}^{-1}$ ) were observed in treatments where the lowest concentration of $B$. bassiana $\left(2.23 \times 10^{7}\right.$ conidia $\left.\mathrm{Kg}^{-1}\right)$ alone was applied against adults of Rhizopertha dominica (F.) (Coleoptera: Bostrichidae). They also witness our results showing the antagonistic behavior of combined EPFs. They reported low rates of mycosis and sporulation in the treatments, where high concentrations of diatomaceous earth were mixed with $B$. bassiana. Similar results were also documented by Tefera and Pringle (2003), who found the highest mycosis and sporulation in cadavers of Chilo partellus (Swinhoe) (Lepidoptera: Pyralidae) treated with $B$. bassiana alone. The results of present finding are in line with the findings of Ashraf et al. (2017) applied $1.4 \times 10^{4} \mathrm{ml}^{-1}$ conidial concentration of $M$. anisopliae individually against stored grain insect pests and reported that percent mycosis and sporulation was high.

Maximum percent pupation and adult emergence in $2^{\text {nd }}$ instar larvae of $P$. gossypiella was observed in treatment where $A I$ extract was applied alone, while minimum percent pupation and adult emergence was observed in treatment where combination of the highest concentrations of $B$. bassiana $+V$. lecanii $+M$. anisopliae along with $A I$ extract was applied. These results are in agreement with Sufyan et al. (2019), who documented that both pupation and adult emergence of $2^{\text {nd }}$ and $4^{\text {th }}$ larval instars of $C$. partellus were maximum at low concentration of entomopathogens (alone and in combination), while minimum pupation and adult emergence were recorded at high concentrations of entomopathogens (alone and in combination).

\section{Conclusion}

This study concluded that the integration of EPFs and $A$. indica extract can prove a successful alternative to traditional chemicals and may become effective component of IPM program against $P$. gossypiella and some other insect pests. Further studies under field conditions are required.

\section{Abbreviations \\ EPF: Entomopathogenic fungi; PDA: Potato dextrose agar; $n$ : Insect population; T: Treated; Co: Control; ANOVA: Analysis of variance; \\ CRD: Complete randomized design; HSD test: Honest significance test; Bb1: Beauveria bassiana $\left(1 \times 10^{6}\right.$ conidia $\left.\mathrm{ml}^{-1}\right)$; Bb2: Beauveria bassiana $(1 \times$ $10^{8}$ conidia $\left.\mathrm{ml}^{-1}\right)$; V/1: Verticillium lecanii $\left(1 \times 10^{6}\right.$ conidia ml $\left.{ }^{-1}\right)$;

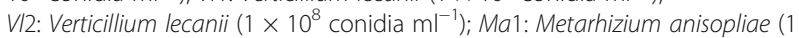

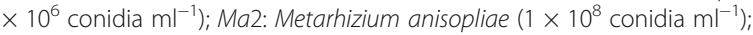 Al: Azadirachta indica extract}

\section{Acknowledgements}

All authors are grateful to AgriLife SOM Phytopharma (India) Limited ${ }^{\oplus}$ (www. agrilife.in) for providing entomopathogenic fungi (Verticillium lecanii, Metarhizium anisopliae and Beauveria bassiana) for conducting this experiment. The authors acknowledge the University of Agriculture Faisalabad (UAF), Pakistan, for according permission to utilize the lab and field associated resources of UAF for the conduct of this part of research. Authors also recognize the support of Punjab Agricultural Research Board (PARB), Pakistan, for providing funds to conduct this part of the research of the PARB funded research project no. 888.

\section{Authors' contributions}

MAF, BA and MDG designed and conducted the experiment, collected and analyzed the data, and wrote manuscript. BA helped in apprehending the idea of this research, designing the layout of experiment and improving the write-up, format, and language of this manuscript. MJA and QAA reviewed the manuscript, add and improved declaration section, edited the format of the tables according to the format of this journal, contributed in data setting for analysis, reviewed the final manuscript, and made the format of this manuscript according to the format of this journal. This final manuscript was ultimately perused, scrutinized, and approved for final submission by all the authors.

\section{Funding}

This experiment was conducted in a Punjab Agricultural Research Board (PARB)-funded project no. 888

\section{Availability of data and materials}

The datasets used and/or analyzed during the current study are available from the corresponding author on reasonable request.

Ethics approval and consent to participate

The authors agree to all the concerned regulations.

\section{Consent for publication}

The authors agree to publish this scientific paper at the Egyptian Journal of Biological Pest Control.

\section{Competing interests}

The authors declare that they have no competing interest.

\section{Author details}

'Department of Entomology, University of Agriculture Faisalabad, (Sub-Campus Burewala, Vehari), Vehari, Punjab, Pakistan. ${ }^{2}$ Rice Research Institute, Kala Shah Kaku, Punjab, Pakistan. ${ }^{3}$ Integrated Pest Management Laboratory, Department of Entomology, University of Agriculture, Faisalabad, Punjab, Pakistan. 
Received: 26 February 2020 Accepted: 5 May 2020

Published online: 27 May 2020

\section{References}

Abbott WS (1925) A method of computing the effectiveness of an insecticide. J Econ Entomol 18(2):265-267

Ali S, Farooqi MA, Sajjad A, Ullah MI, Qureshi AK, Siddique B, Waheed W, Sarfraz M, Asghar A (2017) Compatibility of entomopathogenic fungi and botanical extracts against the wheat aphid, Sitobion avenae (Fab.) (Hemiptera: Aphididae). Egypt J Biol Pest Control 28:97

Ashraf M, Faroog M, Shakeel M, Din N, Hussain S, Saeed N, Shakeel Q, Rajput NA (2017) Influence of entomopathogenic fungus, Metarhizium anisopliae, alone and in combination with diatomaceous earth and thiamethoxam on mortality, progeny production, mycosis, and sporulation of the stored grain insect pests. Environ Sci Pollut Res 24(36):28165-28174

Atta B, Rizwan M, Sabir AM, Gogi MD, Farooq MA, Batta Y (2020). Efficacy of entomopathogenic fungi against Brown planthopper Nilaparvata lugens (Stål) (Homoptera: Delphacidae) under controlled conditions. Gesunde Pflanzen, 72:101-112

Derbalah A, Khidr A, Moustafa HZ, Taman A (2014) Laboratory evaluation of some non-conventional pest control agents against the pink bollworm Pectinophora gossypiella (Saunders). Egypt J Biol Pest Control 24(2):363-368

Dharajothi B, Valarmathi R, Nagarajanm T, Rajan T (2010) Larval sex differentiation of pink bollworm-an easy tool for pairing of adults for mass rearing. CICR Newsletter Nagpur 26(3):5

Dougoud J, Toepfer S, Bateman M, Jenner WH (2019) Efficacy of homemade botanical insecticides based on traditional knowledge. A review. Agron Sustain Dev 39(4):37

Heuberger S, Ellers-Kirk C, Yafuso C, Gassmann AJ, Tabashnik BE, Dennehy TJ, Carrière $Y$ (2014) Effects of refuge contamination by transgenes on Bt resistance in pink bollworm (Lepidoptera: Gelechiidae). J Econ Entomol 101(2):504-514

Jaleel W, Saeed S, Naqqash MN, Zaka SM (2014) Survey of Bt cotton in Punjab Pakistan related to the knowledge, perception and practices of farmers regarding insect pests. Int J Agric Crop Sci 7(1):10-20

Jothi BD, Naik VCB, Kranthi S, Kranthi K, Valarmathi R (2016) Viable mass production method for cotton pink bollworm, Pectinophora gossypiella (Saunders). J Basic Appl Zool 73:9-12

Kenis M, Hurley BP, Hajek AE, Cock MJ (2017) Classical biological control of insect pests of trees: facts and figures. Biol Invasions 19(11):3401-3417

Khan S, Guo L, Maimaiti Y, Mijit M, Qiu D (2012) Entomopathogenic fungi as microbial biocontrol agent. Mol Plant Breed 3(7):63-79

Kurtti TJ, Keyhani NO (2008) Intracellular infection of tick cell lines by the entomopathogenic fungus Metarhizium anisopliae. Microbiol 154(6):1700-1709

Leland J, Gore J (2016) Microbial control of insect and mite pests of cotton. In: Lacey LA (ed) Microbial control of insect and mite pests: from theory to practice. Academic, Amsterdam, pp 185-197

Mathew LK (2016) Botanicals as biopesticides: a review. Int J Adv Res 4(3):1734-1739

Mohamed HO, El-Heneidy AH, Ali AEG, Awad AA (2016) Non-chemical control of the Pink and Spiny Boll worms in cotton fields at Assuit Governorate, Upper Egypt, II-Utilization of the egg parasitoid, Trichogrammatoidea bactrae Nagaraja. Egypt J Biol Pest Control 26(4):807-813

Muralimohan K, Kamath S, Mohan K, Ravi K, Deeba F, Sivasupramaniam S, Head GP (2009) Mass rearing diet for the pink bollworm Pectinophora gossypiella (Lepidoptera: Gelechiidae) and its susceptibility to insecticidal Bt proteins. Int $J$ Trop Insect Sci 29(2):102-107

Niu X, Xie W, Zhang J, Hu Q (2019) Biodiversity of entomopathogenic fungi in the soils of South China. Microorganisms 7(9):311

Nursal, llyas S (2019) The effectiveness of botanical insecticides of four plant types and adjuvants on nutrition index of the fifth instar larvae of Heliothis armigera Hubner. The $4^{\text {th }}$ Int Conf Biol Sci Biotechnol. IOP Conf Ser: Earth Environ Sci 305:1-9

Ong TW, Vandermeer JH (2014) Antagonism between two natural enemies improves biological control of a coffee pest: the importance of dominance hierarchies. Biol Conserv 76:107-113

Parker AG (2005) Mass-rearing for sterile insect release. In: Dyck VA, Hendrichs J, Robinson AS (eds) Sterile insect technique. Principle and practice in areawide integrated pest management. Int Atomic Energy Agency, Springer, The Netherlands, pp 209-232

Parmar VR, Patel CC (2016) Pink bollworm: a notorious pest of cotton: a review. AGRES Int e-J 5(2):88-97
Rajendran S, Sriranjini V (2008) Plant products as fumigants for stored-product insect control. J Stored Prod Res 44(2):126-135

Riasat T, Wakil W, Ashfaq M, Sahi ST (2011) Effect of Beauveria bassiana mixed with diatomaceous earth on mortality, mycosis and sporulation of Rhyzopertha dominica on stored wheat. Phytoparasitica 39(4):325-331

Rizwan M, Atta B, Sabir AM, Yaqub M, Qadir A (2019) Evaluation of the entomopathogenic fungi as a non-traditional control of the Rice leaf roller, Cnaphalocrocis medinalis (Guenee) (Lepidoptera: Pyralidae) under controlled conditions. Egypt J Biol Pest Control 29:10

Sokal RR, Rohlf FJ (1995) Biometry: the principles and practice of statistics biostatistical analysis, $3^{\text {rd }}$ edn. WH Freeman, New York, p 887

Sufyan M, Abbasi A, Wakil W, Gogi MD, Arshad M, Nawaz A, Shabbir Z (2019) Efficacy of Beauveria bassiana and Bacillus thuringiensis against maize stem borer Chilo Partellus (Swinhoe) (Lepidoptera: Pyralidae). Gesunde Pflanzen 71(3):197-204

Świergiel W, Meyling NV, Porcel M, Rämert B (2016) Soil application of Beauveria bassiana GHA against apple sawfly, Hoplocampa testudinea (Hymenoptera: Tenthredinidae): Field mortality and fungal persistence. Insect Sci 23(6):854-868

Tefera T, Pringle K (2003) Effect of exposure method to Beauveria bassiana and conidia concentration on mortality, mycosis, and sporulation in cadavers of Chilo partellus (Lepidoptera: Pyralidae). J Invertebr Pathol 84(2):90-95

Vashisth S, Chandel YS, Chandel RS (2019) Comparative efficacy of indigenous heterorhabditid nematodes from north western Himalaya and Heterorhabditis indica (Poinar, Karunakar \& David) against the larvae of Helicoverpa armigera (Hubner). Int J Pest Manage 65(1):16-22

\section{Publisher's Note}

Springer Nature remains neutral with regard to jurisdictional claims in published maps and institutional affiliations.

\section{Submit your manuscript to a SpringerOpen ${ }^{\circ}$ journal and benefit from:}

- Convenient online submission

- Rigorous peer review

- Open access: articles freely available online

High visibility within the field

- Retaining the copyright to your article

Submit your next manuscript at $\boldsymbol{\nabla}$ springeropen.com 